\title{
Assessment of the factors influencing on the formation of energy-oriented modes of electric power consumption by water-drainage installations of the mines
}

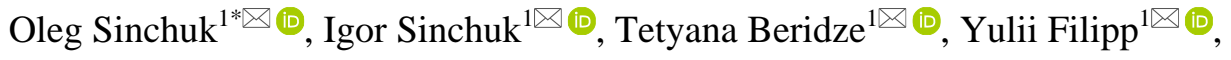 \\ Kyrylo Budnikov $^{1 \otimes(\mathbb{D})}$, Oleg Dozorenko ${ }^{1 \otimes(\mathbb{D})}$, Ryszard Strzelecki ${ }^{2 \otimes(\mathbb{D})}$ \\ ${ }^{1}$ Kryvyi Rih National University, Kryvyi Rih, 50027, Ukraine \\ ${ }^{2}$ Gdańsk University of Technology, Gdańsk, 80-233, Poland \\ *Corresponding author: e-mail speet@ukr.net, tel. +380683496355
}

\begin{abstract}
Purpose. Performing the analysis to determine energy-efficient modes and assess the characteristics of the main indicators of electric power consumption by mine water-drainage installations based on the developed research mathematical model.

Methods. To achieve the purpose set, a methodology is used to develop the multiple multifactor correlation-regression modeling with respect to the modes of electric power consumption by electrical and mechanical complexes of mine waterdrainage installations. The amount of consumed electric power is found as an effective feature. The expediency of using the nonlinear multiple regression analytical ratios has been substantiated during the model development. A comparative analysis of a multiple multifactor regression model, presented in the form of a power and linear function, has been performed.

Findings. The research results make it possible to determine that the greatest influence on the electric power consumption is made by water inflow, and the smallest influence - by the depth of water pumping from underground horizons. The expediency of using a multiple multifactor regression model in the form of a power function has been substantiated. The elaborated quantitative values of the factors of electric power consumption by electrical and mechanical complexes of mine waterdrainage installations have become the basis for the introduction of innovative technological solutions at the relevant iron ore enterprises to optimize the cost characteristics of the electric power consumption.
\end{abstract}

Originality. For the first time for the analysis and assessment of the operating modes of the main water-drainage installations of mines, the use of mathematical modeling based on the multiple correlation-regression method is proposed. The developed model takes into account a complex of technological parameters of influence on the water-pumping process. The analysis of the proposed model makes it possible to identify significant factors influencing the modes of electric power consumption by electrical and mechanical complexes of water-drainage installations in the mines and to conduct waterdrainage assessment for constructing an algorithm for optimal control of this process in the cost-target direction.

Practical implications. The research tactics are proposed for determining the energy-efficient operating modes of the main water-drainage installations of the mines by the method of mathematical modeling. The analysis of the obtained results of mathematical and statistical modeling makes it possible to take into account the complex of technological parameters of the influence on the water-pumping process, to identify and assess the modes of electric power consumption by the main waterdrainage installations, as well as to obtain the initial data for the development of the structure of the control algorithm for mine stationary installations of this type in the cost-target aspect.

Keywords: indicator, regression, model, electric power consumption, water-drainage installations

\section{Introduction}

The mining and metallurgical industry, as in the years of the USSR, and now in Ukraine, is the main one in the country's GDP formation [1], [2]. Meanwhile, if in the days of the USSR this tandem of economy and statehood was dominated by the metallurgical component, then in our time in Ukraine, this role has been taken over by the mining sector [3]. It is thanks to the functioning of this industrial complex that Ukraine is in the top ten world leaders in the extraction of such a strategically important type of minerals as iron ore. This makes it possible to annually replenish foreign exchange reserves by $60-70 \%$ and remain the basic component of both macro and microeconomics of the state [4].

Meanwhile, the production cost of iron ore raw materials (IORM) is growing every year, both for objective reasons 
(increase in the mining depth, which in the underground method exceeds the level of 1500 meters with a prospect of 2000-2300 m), and for a number of subjective ones [5], [6]. This situation has a negative impact on the economy of enterprises, on their competitiveness in the world market of raw materials and on the state economy as a whole.

One of the negatively progressing factors in the growth of production costs for mining the iron ore raw materials is the constant growth of energy segment in this indicator, including its component - electric power (EP) [7]. Thus, in the production costs of mining the iron ore raw materials by underground method, about $30 \%$ of the total volume is energy costs, of which, in turn, more than $95 \%$ falls on electric power costs [8].

In [7], it is proved that an increment in the volume of EP consumption by iron ore mines, without taking into account the increase in electric power prices, is growing annually by more than $1 \mathrm{kWh}$ per 1 ton of mined iron ore raw materials.

Meanwhile, according to the research [9]-[11], including data of the authors in [12]-[15], for these types of enterprises, the problem of electric power efficiency is not limited by the factor of setting the significant electrical capacities and corresponding levels of EP consumption, but is further complicated by significant fluctuations of the above levels during the day, months, seasons.

As determined from the analysis of these processes [13], the continuous EP consumption during the day is characterized by the greatest range of fluctuations. Thus, the range of existing fluctuations in hours of the day in terms of the level of EP consumption by domestic iron ore mines, on average, exceeds 4-fold values [13]. This fact additionally has a negative impact on the energy economy of these enterprises. Such fluctuations in the levels of EP consumption are not observed in any other type of industrial enterprises, including even in the analogs closest to iron ore mines of underground mining method - coal, shale, salt-mining and other types of the mines [10]. This is due to the specificity of the technology for mining the iron ore raw materials and the corresponding types of energy-intensive consumers involved in this process.

Among the iron ore mines, the main water-drainage installations are the most energy-intensive consumers, which consume about $26-33 \%$ of the total volume of consumption with significant levels of fluctuations of the EP consumption during the day [14].

In order to reduce costs for consumed electric power, enterprises, in accordance with the existing hourly time-of-use tariffs, have changed the modes of functioning of the main water-drainage installation by transferring certain periods of their operation to economic - post-peak zones. At the same time, it should be noted that such a positive direction is based rather on the priori vision of this energy-oriented direction than on the realities of the condition and the possibility of achieving a significant positive effect on the cost-target component of payment for consumed electric power.

It is trivial, but strategically correct to assert that the ways to achieve a real level of energy efficiency increase in the main water-drainage installation should be based not only on purely technical solutions, but, first of all, on a perfect multifactor algorithm for controlling the process of EP consumption by a given consumer, taking into account both technological and economic criteria.

In this perspective, additional motivations are required, one of which is not a new, but, so far, insufficiently studied and implemented solution for optimizing the operating modes of the main water-drainage installation in hours of the day with the additional control actions of cost-oriented management, since at present, tariffs are formed mainly in hours of the day per $\mathrm{kWh}$ of consumed electric power.

This solution implementation can be achieved by the control process in the context of the operating scheme development of the corresponding automated control system (ACS) with elements of artificial managerial intelligence. The basic component of this process is the problem of developing an adaptive control algorithm based on the existing set of criteria and constraints [15].

By itself, such an interpretation of the approach to solving the problem of efficiency of the main water-drainage installation operation is not new [16]-[18]. But the presentday realities and potential possibilities of the technological and technical implementation of the corresponding automated control system open up new opportunities for this. Moreover, in recent years, research has intensified on the creation of electric power complexes on the basis of main waterdrainage installations that can operate in the mode of generating electric power during peak hours [19]-[22]. That is, the boundaries of control over the main water-drainage installation operating modes are expanding, and the existing structure of the electrical and mechanical water-drainage complex of the "consumer-regulator" electric power type is transformed into the "consumer-regulator-producer of electric power" option.

The expediency or inexpediency of such an option is not the subject of research in this paper. However, the reality of such a main water-drainage installation development in a synergistic version of functioning has the right to exist as a fact. Meanwhile, it is logical that such a direction additionally complicates the functioning of the main water-drainage installations. This stresses the need for additional research and, above all, to assess the factors influencing on the modes of their operation.

It is in this direction that modern scientific research has been transferred, among which the research of scientists and scientific practitioners of Canada, Germany, South Africa, Australia and a number of other countries is distinguished by its practical orientation [19], [22]. Nevertheless, in the available publications there are no or insufficient coverage of the issues of assessing the levels of EP consumption condition and the water-drainage technology of a particular studied object. This fact to a large extent makes it impossible to assess the level of expediency and, most importantly, the degree of real effectiveness of the proposed solutions.

In recent years, a certain level of scientific intelligence in the analyzed direction has been reviving in the scientific community of Ukraine. Thus, the first positive results have been obtained in a new vision of the energy perspective scheme for the main water-drainage installations of the mines [18], [23], [24].

However, there is still no adequate solution for the "roadmap" formation for increasing the efficiency of the main water-drainage installation operation in iron ore mines. The very same "adequacy" of this process, in the modern version of the vision, should consist in the economic substantiation and assessment of the levels of achieving the maximum possible results in one or another option of decisions. At the same time, no matter how trivial it may seem, purely technical solutions cannot give the expected positive result. 
To achieve the purpose, an integrated assessment is required of the parameters of the main water-drainage installation functioning and determination of the technological and technical parameters influencing on this process, based on the economic energy-directed final option. This forms the logics of research: obtaining real output parameters of the main water-drainage installation functioning with subsequent modeling in order to determine the optimal energy-oriented modes of its operation.

\section{Methods}

Thus, there is an objective need for correlation-regression analysis as one of the most effective economic and statistical methods for identifying the influence of the most significant factors on an effective feature and developing an adequate mathematical model based on it.

It is known that most often when using mathematical and statistical methods, linear regression models are selected, which make possible to easily determine the parameters that are included in these models. Therefore, the structure of the regression equation is set in a linear form:

$W_{p}=a+b \cdot V+c \cdot h+d \cdot(P \cdot n)$,

where:

$W_{p}$ - the amount of consumed electric power, $\mathrm{kWh}$;

$V$ - water inflow, $\mathrm{m}^{3} / \mathrm{h}$;

$h$ - horizon,m;

$P$ - pump capacity, kW;

$n$ - number of pumps, pcs;

$a, b, c, d$-parameters.

To find the parameters included in model (1), it is necessary to solve the system of equations:

$$
\left\{\begin{array}{c}
W_{p}^{(1)}=a+b \cdot V_{1}+c \cdot h_{1}+d \cdot\left(P_{1} \cdot n_{1}\right) \\
\ldots \\
W_{p}^{(i)}=a+b \cdot V_{i}+c \cdot h_{i}+d \cdot\left(P_{i} \cdot n_{i}\right) \\
\cdots \\
W_{p}^{(N)}=a+b \cdot V_{N}+c \cdot h_{N}+d \cdot\left(P_{N} \cdot n_{N}\right)
\end{array}\right.
$$

where:

$W_{p}(i), V_{i}, h_{i}, P_{i}, n_{i}-$ statistical data;

$N$ - the amount of statistical data.

It is known that the condition for solving the system of Equations (2) is its compatibility, in particular, that the number of equations is equal to the number of unknown values. If the number of unknown valus is four, and the number of equations is seven, then the system of equations is incompatible. To get over this difficulty, the least squares method (LS method) is used, which generalizes the concept of solving a system of equations. To do this, a function of the total residual is created in the form of the sum of the residuals from each of the equations:

$$
F(a, b, c, d, e)=\sum_{i=1}^{N}\left(a+b \cdot V_{i}+c \cdot h_{i}+d \cdot\left(P_{i} \cdot n_{i}\right)-W_{p}^{(i)}\right)^{2}
$$

This function is integral and equal to zero when the right and left parts of the calculated system coincide. In this case, the closer the right-hand parts of the system (2) equations to the left-hand parts, the lower the value of the residual function (3). This gives reason to consider the following values of the parameters $a^{*}, b^{*}, c^{*}, d^{*}$ as a solution to system (2), for which the residual function is minimal, that is:

$$
F\left(a^{*}, b^{*}, c^{*}, d^{*}\right)=\min _{a, b, c, d} F(a, b, c, d) .
$$

Thus, to solve the incompatible system of Equations (2), it is sufficient to minimize the function of the total residual (3) as a function of several variables.

To find the parameters, let us use the least squares method in matrix form. To do this, the system of Equations (2) is written in matrix form:

$A \cdot X=W$.

In matrix form, formula (3) is represented as:

$$
F(X)=(A \cdot X-W)^{T} \cdot(A \cdot X-W),
$$

where:

$(.)^{T}$ - matrix transposition.

The minimization problem solution (5) leads to solving the matrix equation:

$$
X^{*}=\left(A^{T} \cdot A\right)^{-1} \cdot A^{T} \cdot W,
$$

where:

$(.)^{-1}-$ inverse matrix.

For comparison, the mathematical model power structure of EP consumption by water-drainage installations is chosen, which is possible, since all variables are positive:

$W_{p}=a \cdot V^{b} \cdot h^{c} \cdot P^{d} \cdot n^{e}$,

where:

$a, b, c, d$-parameters.

To find the parameters, the power structure is reduced to a linear one by taking the logarithm:

$\ln W_{p}=\ln a+b \cdot \ln V+c \cdot \ln h+d \cdot \ln P+e \cdot \ln n$.

To determine the parameters, we use the least squares method by minimizing the functional:

$$
Q(\ln a, b, c, d, e)=\sum_{\left.i=1+d \cdot \ln P_{i}+e \cdot \ln n_{i}-\ln W_{p}^{(i)}\right)^{2}}^{\left(\ln a+b \cdot \ln V_{i}+c \cdot \ln h_{i}\right.}
$$

To calculate, the determination coefficient is found by the formula:

$$
R^{2}=1-\frac{S_{o}^{2}}{D}
$$

where:

$S^{2}{ }_{o}$ - the average sum of statistical data deviations on the EP consumption by water-drainage installations from the calculations by (9);

$D$ - dispersion of statistical data on the EP consumption by water-drainage installations.

To calculate the determination coefficient by (10), the formulas are used:

$S_{o}^{2}=\frac{1}{7} \sum_{i=1}^{7}\left(W_{p}^{(i)}-W_{m}^{(i)}\right)^{2}, D=\frac{1}{6} \sum_{i=1}^{7}\left(W_{p}^{(i)}-\overline{W_{p}}\right)^{2}$,

where: 
$\overline{W_{p}}=\frac{1}{7} \sum_{i=1}^{7} W_{p}^{(i)}$.

The average coefficients of elasticity for linear regression are calculated by the formula:

$$
\overline{E_{y x_{j}}}=b_{j} \cdot \frac{\bar{x}_{j}}{\bar{y}} .
$$

The coefficients indicate the percentage by which, on average, the result can change when the corresponding factor changes by $1 \%$. The average indicators of elasticity can be compared with each other and, accordingly, the factors can be ranked according to the strength of their influence on the result.

Thus, a model is constructed that includes significant factor peculiarities, for which the estimated regression parameters are calculated. Based on the model, conclusions are drawn about the influence of the factors on an effective feature.

\section{Research results}

The specificity and individual peculiarities of the technology of functioning the iron ore enterprises in terms of the unpredictable changes in the parameters of EP consumption by receivers, including the main water-drainage installations, and, therefore, the choice of a suitable model for research is a complex and, to a certain extent, a venture problem.

It is trivial, but, as noted above, the tactics of the scientific search process, as a research complex, for a sufficient level of adequacy to the realities of the results obtained, should provide for both theoretical and experimental components. However, it is impossible to perform experimental research in the required scope under the conditions of operating mines for a number of both technical reasons and the life safety at the enterprise. The modern computer possibilities make it possible to minimize this inconvenience. Therefore, research "roadmap" is drawn up according to such a scheme.

\subsection{Research on the operating modes of the main water-drainage installations in the mines}

The water is pumped out from the underground horizons of ore mines by electrical and mechanical hydropower complexes with a complex structure and operating modes [12]. This is difficult due to the fact that, firstly, the water inflow in the mines and the volumes of water for pumping out are not constant over time (Fig. 1). Secondly, the so-called "wet conservation" of abandoned mines occurs, which leads to "linkage", that is, the joining of underground horizons of adjacent mines into a single complex.

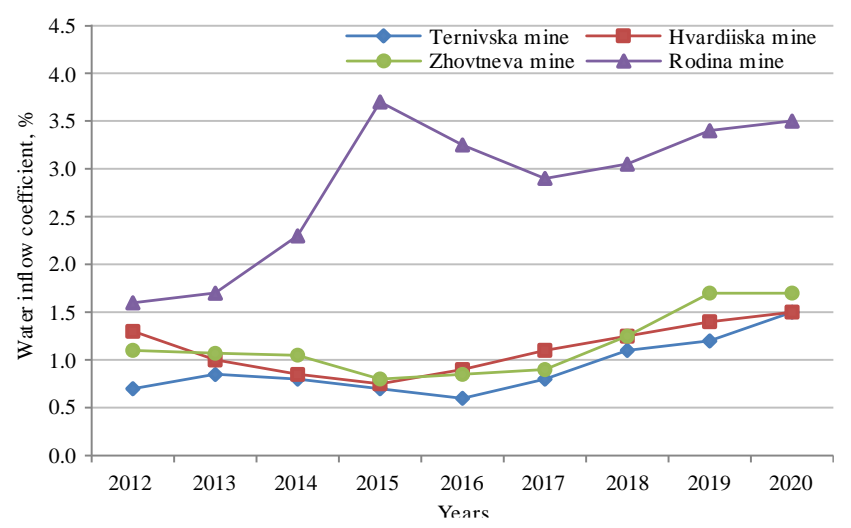

Figure 1. Water inflow coefficient in iron ore mines of Kryvyi Rih
All this predetermines a solution to the problem of choosing the rational operating modes for water-drainage pumps as multilevel electrical and mechanical complexes functioning in a multi-criteria algorithm with a fuzzy forecast [23], [24].

For a certainty of the expected effect that is tangible for the mining enterprise economy and the appropriate measures adopted to change the algorithm for the main water-drainage installation functioning, it is required a differentiated assessment of the corresponding range of technological components influencing on the analyzed drainage process.

Experimental research performed by the authors makes it possible to obtain a definite pattern of these processes.

Table 1 presents the indicators for the water inflow in a number of mines of Ukraine (data provided by the energy services of the certain mines). As can be seen from the information provided, the indicators differ significantly from each other.

Table 1. Average indicators of daily water inflows in iron ore mines for the period of 2012-2021

\begin{tabular}{cc}
\hline Mine & Specific intake of mine water, $\mathrm{m}^{3} /$ day \\
\hline Ternivska & 4452 \\
\hline Hvardiiska & 3042 \\
\hline Zhovtneva & 4110 \\
\hline Rodina & 8989 \\
\hline Frunze & 1800 \\
\hline Yuvileina & 2520 \\
\hline Mittle Stice & 5988 \\
\hline Hihant-Hlyboka & 8551 \\
\hline Ekspluatatsiina & 46000 \\
\hline
\end{tabular}

To analyze the parameters of the main water-drainage installation functioning in the mine, such a parameter as the water inflow coefficient is determined, which is the ratio of the turnover of the annual water inflow $\left(\mathrm{m}^{3}\right)$ to the volume of the annual water inflow into iron ore mines (Fig. 1).

As the graph shows (Fig. 1), this coefficient is not constant and is characterized by a significant level of fluctuations in individual mines. This influences the levels of EP consumption by the main water-drainage installations.

The analysis of EP consumption by electrical and mechanical complexes of water-drainage installations in absolute units for the same period from 2014 to 2020 is given in Figure 2.

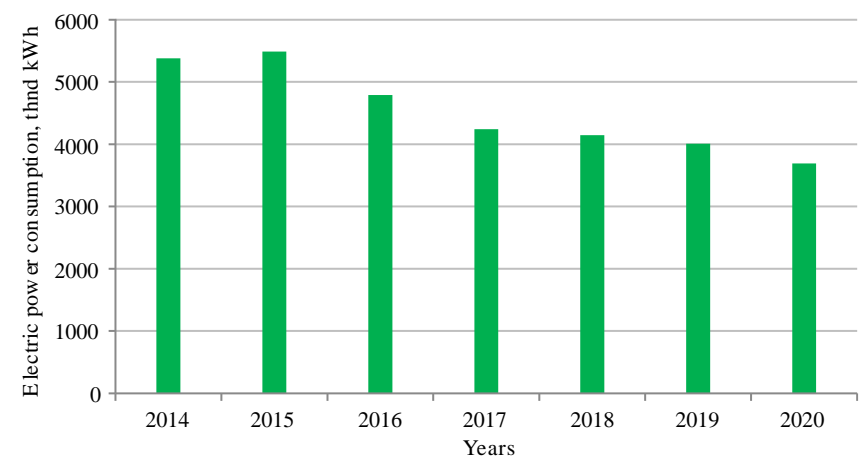

Figure 2. Histogram of the cumulative electric power consumption by water-drainage installations in the mines of the Kryvyi Rih iron ore basin for the period of 2014-2020

As can be seen from Figure 2, there is a decrease in absolute units of the EP consumption for the period of 2020. This can be explained both by the results of the policy implemen- 
ted in the Kryvyi Rih iron ore region to redistribute the water inflow between mines with an emphasis on pumping out of groundwater from existing mines to those that are on "wet conservation", and some organizational a priori measures taken at these mines.

However, this result does not solve the problem, since the total EP consumption by mines has decreased slightly, and the level of payment for consumed electric power has increased significantly. As an example, the Hihant-Hlyboka mine, which is under conservation, consumes more electric power for pumping out of water (Fig. 3) than a number of operating mines (Fig. 4).

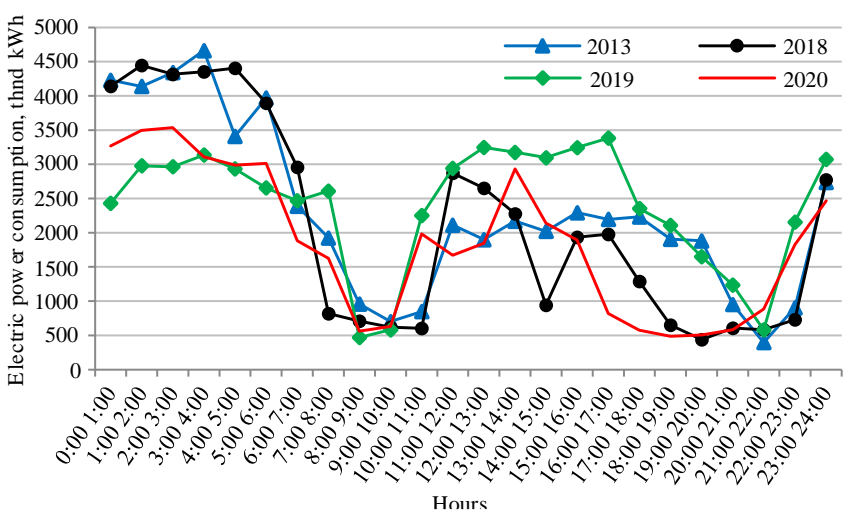

Figure 3. Electric power in hours of the day, consumed by the main water-drainage installation of the Hihant-Hlyboka mine, which is under conservation (Kryvyi Rih)

The dynamics of EP consumption levels, forming the corresponding dynamics of fluctuations in payment for $\mathrm{kW}$ of consumed electric power in hours of the day, stresses the need for enterprises to adapt to these realities.

\subsection{Modeling the process of setting \\ the energy-oriented modes of functioning the main water-drainage installations}

Monitoring and controlling the level of energy efficiency of difficult-to-control technologies for the functioning of such electrical and mechanical systems as water-drainage installations, based on the existing methodological support without its thorough revision, is practically impossible, since it is aimed at using simplified analytical and empirical dependences designed for the same initial data, regardless of the conditions.

When studying the process of forming the EP consumption, interconnection measurement methods play an important role in time, in particular, correlation-regression analysis and the use of nonparametric methods for determining the relationships. It is these methods, which, in conditions that are difficult for the development of control schemes for such enterprises as mines, make it possible to analyze, assess and determine the structure of the algorithm to control the electric power consumed by water-drainage installations.

When studying the process of EP consumption by the main water-drainage installations of iron ore mines, it is expedient to determine the set and content of indicators that can make it possible to more reasonably assess the use of applied and consumed resources at all stages of operation; to plan the current activity of the process of EP consumption by water-drainage installations in iron ore mines; identify reserves to increase the production, etc. (a)

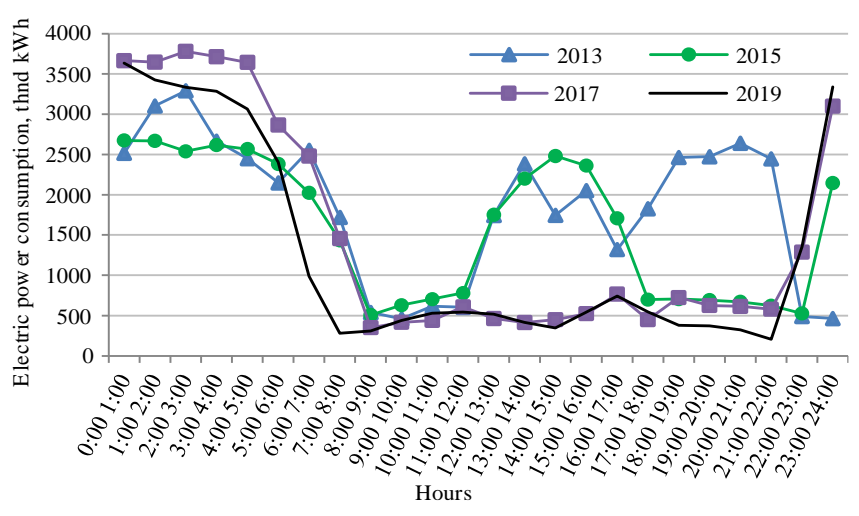

(b)

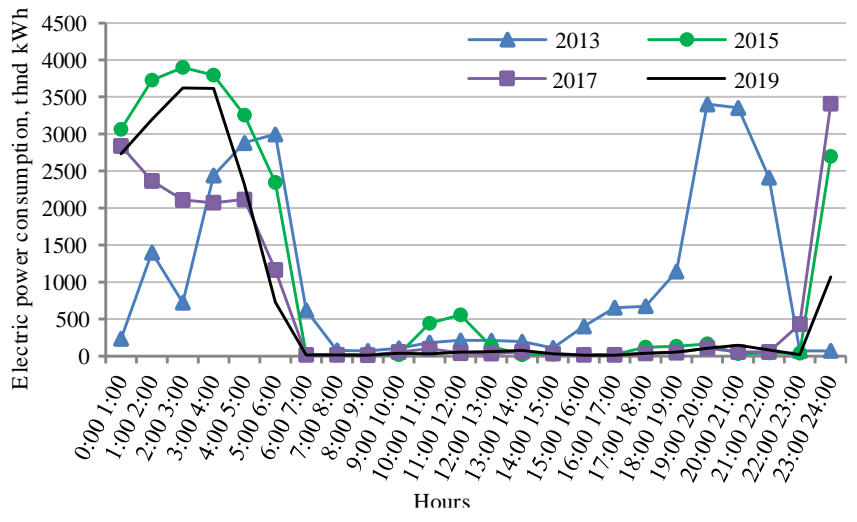

(c)

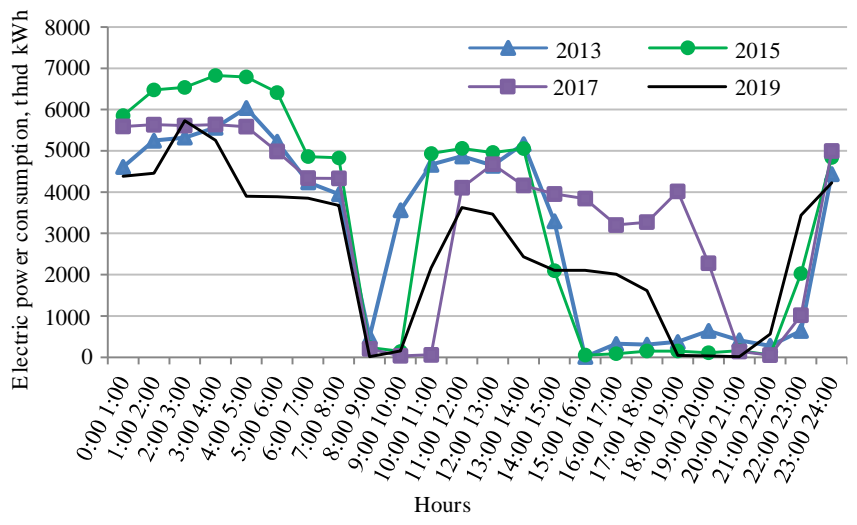

(d)

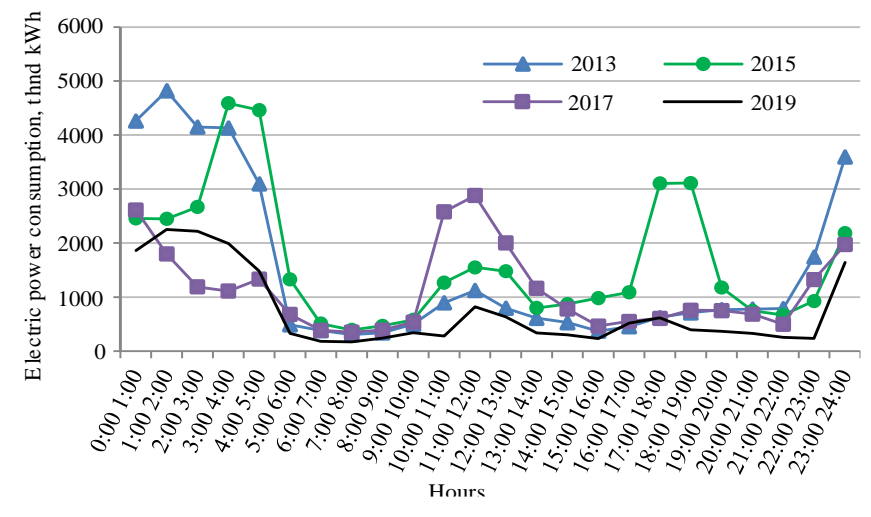

Figure 4. Daily curves of electric power consumed by electric drives of water-drainage installations in a number of mines of the Kryvyi Rih iron ore basin: (a) Ternivska mine; (b) Hvardiiska mine; (c) Rodina mine; (d) Zhovtneva mine 
Thus, under current conditions of the information space structure in the process of electric power consumed by waterdrainage installations in iron ore mines, analytical information should occupy a more significant place. In this regard, the timeliness and reliability of the relevant information becomes an important factor providing the possibility of increasing the efficiency of electric power consumption.

In this case, a special place is occupied by the initial information about the studied object. As a rule, it is characterized by a certain set of spatial features influencing the efficiency of EP consumption as a complex technological process. A large number of factor values necessitates the use of precisely the methods of multiple correlation-regression analysis, which make it possible to distinguish the most statistically significant factors and assess their relationship with the effective feature, which as a result is presented in the form of a certain numerical expression [24]-[27].

It should be especially noted that the solution to each problem must begin with a thorough preliminary analysis. In accordance with the solution to this problem for the analysis and optimization of EP consumption by water-drainage installations, it should be noted that it is necessary to set a relationship in a simplified formulation between the electric power consumed for pumping out the water and the mass of water that is pumped out from a given depth.

Let us use the energy conservation law. To raise the water, it is necessary to do the work:

$A=m \cdot g \cdot h$,

where:

$m$ - mass of water, $\mathrm{kg}$;

$g-$ free fall acceleration, $\mathrm{m} / \mathrm{s}^{2}$;

$h$ - the depth from which the water is raised, $m$.

If the volume of water is taken into account, then (13) takes the form:

$A=\rho \cdot V \cdot g \cdot h$,

where:

$\rho$ - density of water, $\mathrm{kg} / \mathrm{m}^{3}$;

$V$ - water volume, $\mathrm{m}^{3}$.

For converting energy from joules to $\mathrm{kWh}$, the coefficient $\delta=2.78 \cdot 10^{-7} \mathrm{kWh} / \mathrm{J}$ is used.

Then (13) takes the form:

$A=\rho \cdot V \cdot g \cdot h \cdot \delta$.

To develop a regression model, the input and output data are distinguished. In our case, $V$ and $h$ are the input variables, and $W$ is the output variable. (14) combines these variables.

Thus, (14) is a regression model, which takes the form:

$A=0.00272 \cdot V \cdot h$.

But it does not reflect the real situation. According to the presented methodology, the corresponding calculations have been performed. Statistical indicators characterizing the EP consumption by water-drainage installations in the Ternivska mine are presented in Table 2. A detailed research of the above methodology for studying the EP consumption by water-drainage installations is conducted. To study the dependence of the EP consumption by water-drainage installations in the Ternivska mine, the method of mathematical modeling is used to develop a regression model based on the statistical data given in Table 2.
Table 2. Statistical indicators of electric power consumed by the water-drainage installations in the Ternivska mine

\begin{tabular}{cccccccc}
\hline Year & $\begin{array}{c}W_{p}, \\
\mathrm{kWh}\end{array}$ & $\begin{array}{c}V, \\
\mathrm{~m}^{3} / \mathrm{h}\end{array}$ & $\begin{array}{c}h, \\
\mathrm{~m}\end{array}$ & $\begin{array}{c}P, \\
\mathrm{~kW}\end{array}$ & $\begin{array}{c}n, \\
\mathrm{pcs}\end{array}$ & $\begin{array}{c}P \cdot n, \\
\mathrm{~kW} \cdot \mathrm{pcs}\end{array}$ & $\begin{array}{c}W_{m}, \\
\mathrm{kWh}\end{array}$ \\
\hline 2011 & 3268.88 & 177.8 & 527 & 800 & 2 & 1600 & 3305.493 \\
\hline 2012 & 4904.88 & 171.6 & 1050 & 800 & 3 & 2400 & 4870.651 \\
\hline 2013 & 5920.88 & 175.9 & 1200 & 250 & 3 & 750 & 5788.457 \\
\hline 2017 & 10228.7 & 180 & 1350 & 315 & 3 & 945 & 12287.04 \\
\hline 2018 & 14609 & 181 & 1350 & 315 & 3 & 945 & 13334.6 \\
\hline 2019 & 11807.1 & 179 & 1350 & 315 & 3 & 945 & 11239.48 \\
\hline 2020 & 12897.1 & 180.5 & 1350 & 315 & 3 & 945 & 12810.82 \\
\hline
\end{tabular}

Let us distinguish the indicators for which the calculations of $W_{p}, V, h, P, n$ are made.

According to the determined parameters of system (2), in our case the number of unknowns is four, and the number of equations is seven, that is, since $N=7>4$, the system of equations is incompatible. The least squares method is used.

Using the data from the Table 2, the quantitative parameters of equation (4) can be determined:

$$
A=\left(\begin{array}{cccc}
1 & 177.8 & 527 & 1600 \\
1 & 171.6 & 1050 & 2400 \\
1 & 175.9 & 1200 & 750 \\
1 & 180 & 1350 & 945 \\
1 & 181 & 1350 & 945 \\
1 & 179 & 1350 & 945 \\
1 & 180.5 & 1350 & 945
\end{array}\right), W=\left(\begin{array}{c}
3269 \\
4905 \\
5921 \\
10229 \\
14609 \\
11807 \\
12897
\end{array}\right), X=\left(\begin{array}{l}
a \\
b \\
c \\
d
\end{array}\right) .
$$

Substituting the values of the matrices, according to (4), and calculating with the use of the matrix rules, we obtain:

$X^{*}=\left(\begin{array}{c}-193561 \\ 1047.6 \\ 10.61 \\ 3.14\end{array}\right)$.

As a result, according to (7), the following values of the parameters $a^{*}=-193561, b^{*}=1047.6, c^{*}=10.61, d^{*}=3.14$ have been obtained.

Taking into account (8), the regression Equation (1) takes the form:

$W_{m}=-193561+1047.6 \cdot \mathrm{V}+10.61 \cdot h+3.14 \cdot P \cdot n$.

The value of electric power, consumed by water-drainage installations in Ternivska mine, is calculated according to (9) in matrix form:

$W_{m}=A \cdot X^{*}=\left(\begin{array}{c}3305.6 \\ 4870.8 \\ 5788.6 \\ 12287.1 \\ 13334.6 \\ 11239.5 \\ 12810.8\end{array}\right)$

The obtained values (18) are given in the last column of the Table 2 .

In turn, in the power form, according to (7), we have:

$W_{m}=1.81543 \cdot 10^{-7} \cdot V^{0.98193} \cdot h^{0.50013} \cdot P^{0.3914} \cdot n^{-7.5881}$. 
Figure 5 shows the calculation results according to (19), which indicate a good approximation to statistical data and practically do not differ from the calculation results according to Formula (5), that is, for the linear structure of the mathematical model.

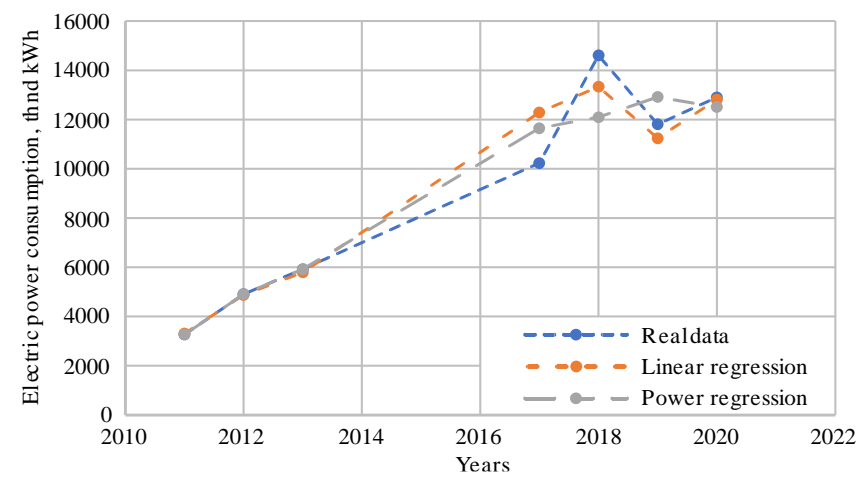

Figure 5. Real and calculated values of multiple linear and power regression models

Substituting the data in Table 2 in (11), we determine $S^{2}{ }_{o}=887220, D=19179437.4$. Then, according to (10), we calculate the determination coefficient $R^{2}=0.954$. It should be emphasized that for the power structure of the mathematical model, the determination index is $R^{2}=0.9275$.

Comparison of the determination coefficient and the index of determination indicates their approximate equality, which evidences a practical coincidence of the results of modeling by linear and power structures.

Visual analysis of curves in Figure 5 confirms the above statements.

After performing an analytical analysis of the multifactor power model, it can be concluded that (19):

- there is a marginal efficiency, which characterizes the increase per unit of the marginal increase in the volume of EP consumption in the case of a change in each factor per unit. Thus, a change in water inflow leads to an increase in the volume of EP consumption by 0.982 ; horizon is increased by 0.5 ; capacity of pumps - by 0.391 ; number of pumps leads to a decrease in EP consumption by 7.588 ;

- the value of the calculated total elasticity indicates that with a simultaneous increase by $1 \%$ of all the considered factors, the value of the indicator of electric power consumed by water-drainage structures at iron ore enterprises is $5.715 \%$.

The calculated determination indexes have confirmed the correctness of selected nonlinear models.

In accordance with the methodology of multiple correlation-regression analysis, calculations have been made for industrial enterprises to conduct a corresponding research.

The constructed multiple regression models for specific iron ore enterprises are given in Table 3.

Table 3. Multiple regression models

\begin{tabular}{cc}
\hline Mine & Multiple regression equations \\
\hline $\begin{array}{c}\text { Zhovtneva } \\
\text { mine }\end{array}$ & $y=1426.31+2.29 \cdot x_{1}+4.19 \cdot x_{2}+3.77 \cdot x_{3}-9.28 \cdot x_{4}$ \\
\hline $\begin{array}{c}\text { Rodina } \\
\text { mine }\end{array}$ & $y=167.63+4.59 \cdot x_{1}+1.67 \cdot x_{3}-3.62 \cdot x_{4}$ \\
\hline
\end{tabular}

When analyzing the obtained indicators (Table 3), the following should be noted: an increase in the factor feature $(X 1)$ of water inflow by $1 \%$ in the Zhovtneva mine can lead to an increase in the volume of EP consumption by $1.89 \%$; an increase in the factor feature $(X 2)$ of the underground horizon depth by $1 \%$ can lead to an increase in the volume of EP consumption by $3.89 \%$, and an increase in the factor feature (X3) of the pump electric drive capacity by $1 \%$ can lead to an increase in the volume of EP consumption by $3.87 \%$. As for the factor feature $(X 4)$, which signifies the number of operating pumps, the EP consumption can decrease by $9.39 \%$.

According to the Rodina mine, an increase in the factor feature $(X 1)$ leads to an increase in EP consumption by $3.78 \%$, an increase in the factor feature $(X 3)$ leads to an increase in EP consumption by $1.89 \%$; an increase in the factor feature $(X 4)$ leads to a decrease in EP consumption by $3.78 \%$.

The conducted research makes it possible to draw some basic conclusions: the factor of the water inflow volume has a greater influence; a factor feature, such as the determined electrical capacity of the pump electric drives can be considered essential. Such a factor feature as the depth of water pumping from underground horizons, as shown by the multiple regression model analysis on the example of the Rodina mine, can be considered insignificant.

At the same time, it is advisable to note that the small volume of statistical data does not allow the use of statistical criteria to confirm the results obtained. Thus, it is expedient to use the results obtained for interpolation purposes, that is, within the ranges of changing the variables.

\section{Conclusions}

The proposed research methodology for determining the energy-efficient modes of functioning of the main waterdrainage installations in the mines using the method of mathematical modeling makes it possible to identify and assess such modes at a specific, separately taken underground enterprise, taking into account the complex of technological parameters influencing on the water-pumping process. On the basis of the methodology, developed and proposed for practical implementation, a multiple correlation-regression model for the modes of electric power consumed by waterdrainage installations in the mines has been constructed and analyzed. This made possible to reveal that the greatest impact on EP consumption is the water inflow factor, and the smallest - the depth of water pumping from underground horizons. It has been determined that with an increase in underground water inflow by $1 \%$ (with a constant level of the share of other factors), the volume of EP consumption increases by $5.715 \%$.

The dependences of the influence of technological parameters in the underground iron ore mining at the level of EP consumption by the main water-drainage installations of the mines have been determined, which make possible to develop the algorithm of their functioning for the conditions of the individuality of a separately taken enterprise with the possibility of variation of the disturbing factors.

\section{Acknowledgements}

The authors express their deep gratitude to the administration of NVK Kryvorizhelektromontazh for assistance in selecting materials and sponsorship for the publication of this paper, as well as the staff of electrical supervisor and energy management of Kryvyi Rih Iron Ore Plant (KZHRK) for the opportunity to conduct experimental research. 


\section{References}

[1] Shydlovskyi, A.K., Pivniak, H.H., Rohoza, M.V., \& Vypanasenko, S.I. (2007). Heoekonomika ta heopolityka Ukrainy. Dnipropetrovsk, Ukraina: Natsionalnyi hirnychyi universytet, $282 \mathrm{p}$.

[2] Stratehiia staloho rozvytku "Ukraina - 2020”. (2017). Rozporiadzhennia Kabinetu Minsistriv Ukrainy \#605-r vid 18 serpnia 2017 roku. Kyiv, Ukraina: Kabinet Minsistriv Ukrainy.

[3] Vilkul, Yu., Azaryan, A., Kolosov, V., Karamanyts, F., \& Batareev, A. (2017). Suchasnyy stan zalizorudnoyi haluzi, prohnoz rozvytku ta propozytsiyi. Sbornik Nauchnykh Trudov "Kachestvo Mineral'nogo Syr'ya", 9-24.

[4] Babets, Ye., Melnikova, I., Grebenyuk, S., \& Lobov, V. (2015). Doslidzhennya tekhniko-ekonomichnykh pokaznykiv hirnychodobuvnykh pidpryyemstv Ukrayiny ta efektyvnosti yikh roboty $v$ umovakh zminnoyi ko 'yuktury svitovoho rynku zalizorudnoyi syrovyny. Multi-authored monograph. Kryvyi Rih, Ukraina: NDGRI DVNZ "KNU", $391 \mathrm{p}$

[5] Riabets, V.V., Dolhyi, A.S., \& Tarasiutin, V.M. (2012). Pidhotovka ta vidpratsiuvannia pryrodno-bahatykh zalizorudnykh pokladiv v umovakh hlybokykh horyzontiv. Stalyi Rozvytok Promyslovosti ta Suspilstva, (1).

[6] Stupnik, M.I., Fedko, M.B., \& Pysmennyi, S.V. (2018). Problemy rozkryttia ta pidhotovky rudnykh rodovyshch na hlybokykh horyzontakh shakht Kryvbasu. Visnyk Kryvorizkoho Natsionalnoho Universytetu, (47), 3-8. https://doi.org/10.31721/2306-5451-2018-1-47-3-8

[7] Kaplenko, Yu.P., \& Yanov, E.K. (2006). Vliyanie glubiny gornykh rabot na tekhniko-ekonomicheskie pokazateli podzemnoy dobych rudy. Visnyk KTU, 5(15), 25-28.

[8] Sinchuk, O., Kupin, A., Sinchuk, I., Rohoza, M., \& Plieshkov, P. (2020). Certain aspects concerning the development of a functioning scheme of the auto-mated system to control energy flows of underground iron-ore enterprises. Mining of Mineral Deposits, 14(3), 101-111. https://doi.org/10.33271/mining 14.03.101

[9] Dremin, A.A. (2006). Strategiya energosberezheniya pri dobyche pererabotke zheleznykh rud. Gornyy Zhurnal, (12), 45-47.

[10] Prakhovnik, A.V., Rozen, V.P., \& Degtyarev, V.V. (1985). Energos beregayushchie rezhimy elektrosnabzheniya gornodobyvayushchikh predpriyatiy. Moskva, Rossiya: Nedra, $232 \mathrm{~s}$

[11] Volynets, V.I. (2012). Analiz efektyvnosti spozhyvannia elektroenerhi vuhilnymy shakhtamy. Enerhetychna Bezpeka Navkolyshnoho Seredovyshcha, 35-36.

[12] Sinchuk, I.O., Karamanyts, F.I., \& Osadchuk, Yu.G. (2019). Electric engineering of iron ore underground enterprises. Current status and prospects. Multi-authored monograph. Warsaw, Poland: iScience Sp. z o. $0,77 \mathrm{p}$.

[13] Sinchuk, I. (2019). Introduction to the formation of the basic structure of the algorithm for the control of electric energy flows in iron ore mines. 2019 IEEE International Conference on Modern Electrical and Energy Systems (MEES). https://doi.org/10.1109/mees.2019.8896426

[14] Sinchuk, I., Boiko, S., Baranovska, M., Kozakevich, I., Syomochkyn, A. Kalmus, D., Peresunko, I., Vinnik, M., Lokhman, N., \& Chorna, V.
(2019). Brief commentaries on the problem of power consumption management at iron ore underground mines. Multi-authored monograph. Warsaw, Poland: iScience, $96 \mathrm{p}$.

[15] Sinchuk, O., Kupin, A., Sinchuk, I., Dozorenko, O., \& Krasnopolsky, R (2020). Algorithms design for fuzzy control by power streams in conditions of underground extraction of iron ore. IEEE 7th International Conference on Energy Smart Systems (ESS), 330-334. https://doi.org/10.1109/ESS50319.2020.9160168

[16] Shevchuk, S.P. (1992). O vliyanii vnepikovogo upravleniya elektropotrebleniem vodootliva gornykh predpriyatiy na dopustimoe vremya pereryva v ego rabote. Vestnik KPI "Seriya Gornoy Elektromekhaniki i Avtomatiki", (23), 34-38.

[17] Kholomenyuk, M.V. (2007). Methods of calculations for pump stations of mining enterprises: Methodological guidelines for mechanical engineering students. Dnipro, Ukraine: National Mining University.

[18] Razumnyy, Yu.T., \& Il'chenko, E.S. (2004). Problemy ispol'zovaniya vodootlivnykh ustanovok ugol'nykh shakht v kachestve protrebiteleyregulyatorov. Girnycha Elektromekhanika ta Avtomatyka, (73).

[19] Rycroft, M. (2017). Small pumped water storage systems: A new partner for renewable energy. Technology \& Business for Development. Retrieved from: https://www.ee.co.za/article/small-pumpedwater-storage-systems-new-partner-renewable-energy.html

[20] Pujades, E., Orban, Ph., Bodeux, S., Archambeau, P., Erpicum, S., \& Dassargues, A. (2017). Underground pumped storage hydropower plants using open pit mines: How do groundwater exchanges influence the efficiency. Applied Energy, (190), 135-146. https://doi.org/10.1016/j.apenergy.2016.12.093

[21] McKinstry, L. (2020). Moriah hydro project proceeds. Retrieved from: http://www.processrepublican.com/news/localnews

[22] V Germanii ugol'nuyu shakhtu prevratyat v gidroakkumuliruyush$\begin{array}{lll}\text { chuyu elektrostantsiyu. (2019). Retrieved from: } & \end{array}$ https://geektimes.ru/post/287320/

[23] Tolmachov, S.T., \& Ilchenko, O.V. (2017). Optymizatsiia rezhymiv roboty nasosnykh ustanovok holovnoho vodovidlyvu shakht za kryteriiem minimumu vartosti elektroenerhii. Visnyk KNU, (44), 137-142.

[24] Sinchuk, O., Sinchuk, I., Kozakevych, I., Fedotov, V., Serebrenikov, V., Lokhman, N., Beridze, T., Boiko, S., Pyrozhenko, A., \& Yalova A. (2018). Development of the functional model to control the levels of electricity consumption by underground iron-ore enterprises. EasternEuropean Journal of Enterprise Technologies, 6(3(96), 20-27. https://doi.org/10.15587/1729-4061.2018.148606

[25] Toporkova, O.A., \& Savchuk, L.M. (2015). Formuvannia intehrovanoi systemy upravlinnia enerhovytratamy na trubnomu pidpryiemstvi. Ekonomichnyi Visnyk, (23), 101-109.

[26] Bodianskyi, Ye.V., Kucherenko, Ye.I., Mykhalov, O.I., Filatov, V.O. Hasyk, M.M., \& Kutsyn, V.S. (2011). Metody obchysliuvalnoho intelektu $v$ systemakh keruvannia tekhnolohichnymy protsesamy ferosplavnoho vyrobnytstva. Dnipropetrovsk, Ukraina: NmetAU, $419 \mathrm{~s}$

[27] Pearson, J. (1966). Decomposition, coordination, and multilevel systems. IEEE Transactions on Systems Science and Cybernetics, 2(1), 36-40. https://doi.org/10.1109/tssc.1966.300076

\section{Оцінювання впливових факторів для формування енергооріснтованих режимів споживання електричної енергії водовідливними установками шахт}

\section{О. Сінчук, І. Сінчук, Т. Берідзе, Ю. Філіпп, К. Будніков, О. Дозоренко, Р. Стжелецкі}

Мета. Проведення аналізу з визначення енергоефективних режимів та оцінювання характеристик основних показників споживання електричної енергії водовідливними установками шахт на основі розробленої дослідницької математичної моделі.

Методика. Для досягнення поставленої мети застосована методика побудови множинного багатофакторного кореляційнорегресійного моделювання щодо режимів електроспоживання електромеханічними комплексами водовідливних установок шахт. В якості результативної ознаки визначено кількість спожитої елек-тричної енергії. Доведено доцільність застосування в процесі розбудови моделі нелінійних множинних регресійних аналітичних співвідношень. Проведено порівняльний аналіз множиної багатофакторної регресійної моделі представленої у формі степеневої та лінійної функції.

Результати. Результати дослідження дозволили установити, що найбільший вплив на споживання електричної енергії становить водоприток, а найменший - глибина відкачування води з підземних горизонтів. Обгрунтовано доцільність застосування множиної багатофакторної регресійної моделі у формі степеневої функції. Опрацьовані кількісні значення чинників електроспоживання електромеханічними комплексами водовідливних установок шахт стали підгрунтям щодо впровадження іноваційних технологічних рішень на відповідних залізорудних підприємствах задля оптимізації вартісних характеристик споживання електричної енергії.

Наукова новизна. Вперше, для аналізу та оцінки режимів функціонування головних водовідливних установок шахт, запропоновано застосування математичного моделювання на засадах множинного кореляційно-регресійного методу. Побудована модель враховує комплекс технологічних параметрів впливу на процес водовідкачування. Аналіз запропонованної моделі дозволяє виявити суттєві чинники впливу щодо режимів електроспоживання електромеханічними комплексами водовідливних установок шахт та провести відвовідне оцінювання задля розбудови алгоритму оптимального керування цим процесом у вартісно-цільовому спрямуванні. 
Практична значимість. Запропонована тактика досліджень з встановлення енергоефективних режимів функціонування головних водовідливних установок шахт методом математичного моделювання. Аналіз отриманих результатів математикостатистичного моделювання дозволяє враховувати комплекс технологічних параметрів впливу на процес водовідкачування, виявити та провести оцінювання режимів споживання елект-роенергії головними водовідливними установками та отримати вихідні дані для розбудови структури алгори-тму керування даним видом стаціонарних установок шахт у вартісно-цільовому аспекті.

Ключові слова: показник, регресія, модель, електроспоживання, водовідливні установки

\section{Оценка влиятельных факторов формирования енергоориентированных режимов потребления электрической энергии водоотливными установками шахт}

\section{О. Синчук, И. Синчук, Т. Беридзе, Ю. Филипп, К. Будников, О. Дозоренко, Р. Стжелецки}

Цель. Проведение анализа по определению энергоэффективных режимов и оценки характеристик основных показателей потребления электрической энергии водоотливными установками шахт на основе разработанной исследовательской математической модели.

Методика. Для достижения поставленной цели применена методика построения множественного многофакторного корреляционно-регрессионного моделирования относительно режимов электропотребления электромеханическими комплексами водоотливных установок шахт. В качестве результативного признака определено количество потребленной электрической энергии. Доказана целесообразность применения в процессе развития модели нелинейных множественных регрессионных аналитических соотношений. Проведен сравнительный анализ множественной многофакторной регрессионной модели представленной в форме степенной и линейной функции.

Результаты. Результаты исследования позволили установить, что наибольшее влияние на потребление электрической энергии составляет водоприток, а наименьшее - глубина откачки воды из подземных горизонтов. Обоснована целесообразность применения множественной многофакторной регрессионной модели в форме степенной функции. Обработаны количественные значения факторов электропотребления электромеханическими комплексами водоотливных установок шахт стали основой по внедрению инновационных технологических решений на соответствующих железорудных предприятиях для оптимизации стоимостных характеристик потребления электрической энергии.

Научная новизна. Впервые для анализа и оценки режимов функционирования главных водоотливных установок шахт, предложено применение математического моделирования на основе множественного корреляционно-регрессионного метода. Построенная модель учитывает комплекс технологических параметров влияния на процесс водооткачки. Анализ предложенной модели позволяет выявить существенные факторы воздействия в отношении режимов электропотребления электромеханическими комплексами водоотливных установок шахт и провести соответствующее оценивание для развития алгоритма оптимального управления этим процессом в ценностно-целевом направлении.

Практическая значимость. Предложенная тактика исследований по установлению энергоэффективных режимов функционирования главных водоотливных установок шахт методом математического моделирования. Анализ полученных результатов математикостатистического моделирования позволяет учитывать комплекс технологических параметров влияния на процесс водооткачки, выявить и провести оценку режимов потребления электроэнергии главными водоотливными установками и получить исходные данные для развития структуры алгоритма управления данным видом стационарных установок шахт в ценностно-целевом аспекте.

Ключевые слова: показатель, регрессия, модель, электропотребления, водоотливные установки 